\title{
THE ANTIQUITY OF KURMANJI KURDISH AND THE BIBLICAL BOOK OF NAHUM
}

\section{Hasan KARACAN (ii) 1 \\ Aviva BUTT (iD) 2}

1 Cyprus Science University, Faculty of Tourism, h_karacan@hotmail.com

2 Independent scholars, Tasmania, Australia: avivabutt@winshop.com.au *Correspondent Author.

\author{
Article history: \\ Submission 24 October 2020 \\ Revision 28 January 2021 \\ Accepted 26 March 2021 \\ Available online 30 April 2021
}

\section{Keywords:}

Jews of Kurdistan,

Kurdish Jews,

Book of Nahum,

Kurmanji Kurdish,

Oldest Kurdish dialect,

Nineveh,

Assyrian Conquest,

Mosaic Religion.

DOI:

https://doi.org/10.32936/pssj.v5i1.206

\begin{abstract}
A b s t r a c t
The biblical Book of Nahūm explains the way HaShem (The Name) deals with Evil. An inner biblical interpretive technique is used to reach this meaning, a technique inconsistent with the method of the rest of the Hebrew Bible. As a prophetic song, the Book of Nahūm rightly prophesies the pending downfall of the Assyrian Empire. In the light of the story of the Jews of Kurdistan together with a careful reading of Nahūm's book, there is enough evidence to assert that the Book has passed through oral translations and various oral recitations. Thus, as oral literature, Nahūm's "book," in actuality a long poem in three sections has been transmitted not only in the original Hebrew but also through Kurmanji Kurdish and neo-Aramaic translations before the final Hebrew redaction took place. Accordingly, the biblical text throws light on not only an episode in ancient history, but also on the antiquity of the Kurmanji dialect and its vernaculars.
\end{abstract}

\section{Introduction}

In recent times, it is possible to define Kurmanji Kurdish (northern Kurdish) as most likely the oldest Kurdish dialect and also a separate dialect from Central Kurdish (southern Kurdish). Central Kurdish has been standardized along with its archaisms and called "Sorani," and Kurdish is now defined as having two main dialects, each with local variations or vernaculars. From the University of Manchester Project, Yaron Matras' Archive of Endangered and Smaller Languages, we read (University of Manchester Project):

Kurdish is a Northwest Iranian language (and as such affiliated to the Indo-Iranian branch of the Indo-European language phylum), related most closely to Persian and transitional varieties spoken along the Iraq-Iran border, such as Hawrami, Gurani, Luri and others, as well as to Dimli (Zazaki), which is spoken in dispersed communities within the Kurdish-speaking areas. The northern varieties of Kurdish are known as Kurmanji (and in Iraq as Bahdini), those spoken in the south of the region are known as Sorani. The dividing line is situated roughly between the towns of Mosul and Rawandiz to the north, and Arbil and Mahabad to the south. The reality on the ground, however, is one of a continuum of dialects, and there is considerable differentiation especially around the transition areas and within the dialects of Sorani.

Kurmanji Kurdish could have been a lingua franca alongside or even preceding Aramaic. As Khanna Omarkhali writes - "the description of the corpus of the Alevis' orally transmitted religious texts in Kurmanji, and their rituals" (Omarkhali, 2019). Kurmanji makes available the cumulative range of its extensive vocabulary, a vocabulary that tends not to lose words but rather to build or add new words to express changing concepts throughout the ages. If we thought to trace etymologies of words in the usual manner through the literature of the ages, as for Kurmanji's ancient literature, it belonged to oral societies that transmitted religious literature and rituals, dramatic narratives, folktales and so forth orally, and sometimes even in translation to other languages. Therefore, it is unusual and only in a limited way is it possible to find something of a trace attesting to the existence 
of creativity such as Omarkhali's description implies. To turn to the poetry of the modern Syrian-Kurdish poet Salīm Barakāt, we see that he speaks Central Kurdish in his home environment and he also speaks the language of the country he lives in; that is to say, he speaks Central Kurdish at home, and not Arabic the language of Syria and the language of most of his poems (Berekat, 2016). As a poet, he is able to transmit ancient grammatical structures and poetic devices stemming from his knowledge of Kurdish dialects and vernaculars when he makes use of the ancient oral genre Shāhnāma. That is, he writes not in any Persian or Turkic language, but rather in the Arabic language whose literature does not know this particular genre. And in so doing, he adds an underlying structure and layer of meaning, as well as innovative uses of Arabic vocabulary, originating in a language such as Kurdish that grew up from the oral culture of oral societies (Butt, 2020d). Searching for texts of this nature - that is, texts evidencing the antiquity of Kurmanji Kurdish through its literary creativity in another language, the story of the Jews of Kurdistan has led the present writers to al-Qūsh on the plain of Nineveh in Iraq, the location of the shrine of biblical prophet Nahūm. That Nahūm's prophetical poem, the Book of Nahūm underwent more than one translation including translation to Kurmanji before its final redaction in Hebrew in the canonized biblical text is an unusual find. In much the same way as Salīm Barakāt can write a Kurdish poem in Arabic that is in a genre strange to Arabic, so Nahūm's poem that this Hebrew prophet who most certainly also spoke both Kurmanji and possibly neo-Aramaic presumably composed in Hebrew could be translated by means of the creative ability of another poet, committed to memory, and recited in a variety of ways by various poets before being committed to writing in Hebrew in its final literary form as the Book of Nahūm. It is easy to understand that Nahūm's Book has perplexed conventional biblical criticism as regards its extensive vocabulary and structure, both of which differ from the rest of Hebrew Bible; at the same time Nahūm displays a thorough knowledge of other biblical books preceding his own prophetical poem.

Nahūm's Book is a long poem divided into three sections, possibly part of a much longer epic in the oral genre Shāhnāma, an ancient genre developed to recount ancient Persian, Turkic, and Kurdish epics (Chamanara, 2013). It typically uses the distich along with syllabic metres. The first section of Nahūm's Book is a song of praise (panegyric) introducing the main protagonist. The genre Shāhnāma was wont to introduce a new character in a song of praise, followed by dramatic narration. The other two sections of Nahūm's Book carry on with dramatic narration. In the case of the modern secular poet Salīm Barakāt, his long poem

\footnotetext{
${ }^{1}$ Line 1: a title, heading or "superscription." The Hebrew $\mathrm{Ha}$ meaning "the" is redundant before Ha-ElQoshi

${ }^{2}$ As the name of the Holy One cannot be uttered, the translator has used the customary stand-in, i.e. HaShem (The Name).The
}

entitled Mahmūd Darwīsh also has three sections, the first section introducing and eulogizing his friend the poet Maḥmūd Darwīsh. In this case, Barakāt's first section consists of a series of short episodes such as might appear in Persian, Turkic or Kurdish epics. As does Nahūm, he carries on with two sections of narrative. Accordingly, we maintain that both poems are in the genre Shāhnāma despite the languages of the poems under scrutiny being Hebrew and Arabic. An important difference is that Nahūm's poem passed through recitations and translations in oral societies, whereas Salīm Barakāt about 2,500 years later in times of general literacy recorded his poem in writing from the start. To summarize, it seems Barakāt's poem has the same structure as the biblical Book of Nahūm - both seem to be extracts from what should be the existence of a longer oral poem in the genre Shāhnāma. Moreover, although both poems are now written literature, they nonetheless still clamor to be read aloud.

\section{Nahum's Initial Fourteen Verse Poem of Praise in Hebrew}

The Book of Nahum 1:1-14

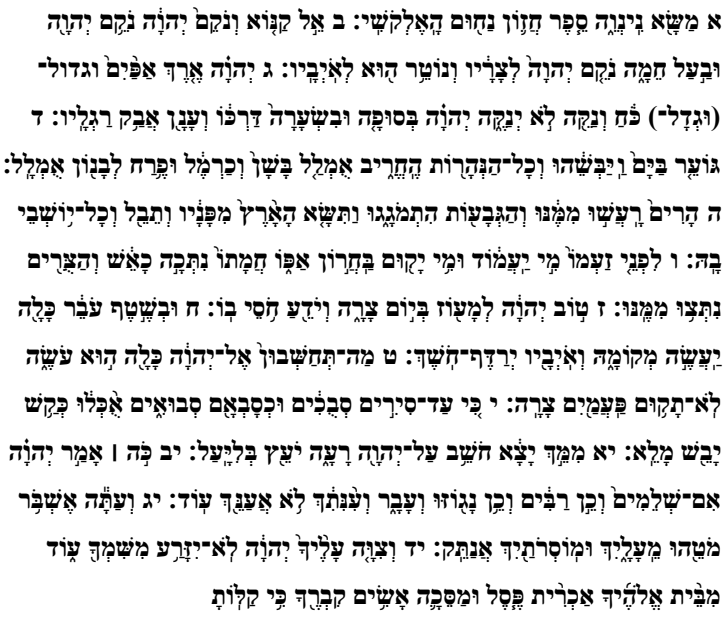

(Torah Database: https://mechon-mamre.org/c/ct/c0.htm)

A new translation of the book of Nahūm 1:1-14 (from the Hebrew):

1:1 The Prophecy of Nineveh: the Book of the Vision of Nahüm of el-Qosh. ${ }^{1}$

1:2 HaShem is a god (who) warns and avenges; HaShem avenges and (being) just, HaShem avenges to the grief and detriment of His adversaries. ${ }^{2}$

opening verse, suggestive of Exodus 34:6-7, lets us know that the poem is in praise of HaShem. 
1:3 HaShem is slow to anger and has great power; ${ }^{3}$ HaShem shall not utterly destroy in the whirlwind or storm [shift-in-meaning] of His path; and cloud is dust at His feet: ${ }^{4}$

1:4 Rebuking the sea, He dries it up and does away with all the rivers; wretched are Bashan and Carmel and the flower of Lebanon, miserable: ${ }^{5}$

1:5 Mountains stir because of Him and the hills glow and the Land becomes molten; and the earth is borne before Him and all the inhabitants with it.

1:6 In the face of his rage who will stand and who will rise against the heat of his burning wrath; and the cliffs will be demolished due to Him:

1:7 HaShem is benign for sheltering [Kurdish construction] in times of trouble (Radnia, 2020); ${ }^{6}$ and knowing those with respect for Him: [An interjection by way of reassurance to the listener] 1:8 And with a passing deluge He will put an end to a place; and darkness shall pursue His enemies:

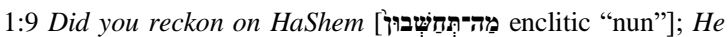
will put an and. ${ }^{7}$ not twice will (this) trouble exist ${ }^{8}$

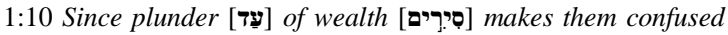
and like their patriarch [Noah] intoxicated, they shall be totally consumed like dry straw:

1:11 From you [singular when addressing the crowd] came forth one plotting evil against HaShem, advising by rationalizing:

1:12 Thus said HaShem and although intact and indeed many, indeed they shall be cut down and pass by; and I have afflicted you, I shall afflict you no more:

1:13 And I am about to shatter its [Nineveh's] control over you and set you free: ${ }^{9}$

1:14 And HaShem commanded concerning you, let your name be sown no more, from the house of your gods I shall excise sculptures and images; I shall prepare your grave since I despise you [an alternate reading: for easing (these events) for you] ${ }^{10}$

In his poem, Nahūm leans on and elucidates other parts of the Hebrew Bible, revealing his penetrating knowledge of Mosaic religion. Thus, in the background we feel the second and fourth book of the Five Books of Moses, Exodus 34:5-7:11

\footnotetext{
${ }^{3}$ In Exodus and Numbers, "rav" means "have" (And has

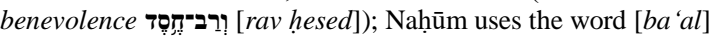
"have."

${ }^{4}$ Storm changes from being a noun to become a verb. Cloud at his feet corresponds with Exodus 34:5.

5 Flower of Lebanon: the flower פרח perah that grows on the plains of Sharon. By using a simple generic term for flower, the poet points to the biblical Song of Songs 2:1 - usually translated as: I am the rose (תבצלת) of Sharon ... the literal meaning of חבצלת havatselet is probably "the primordial flower of Sharon." ${ }^{6}$ For sheltering / to shelter (same meaning): On "l" plus verbal

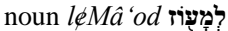

${ }^{7}$ The words "to Nineveh" are not recited aloud because Nineveh is evil.
}

34:5 And HaShem descended on a cloud [grammar: use of ergative] and came to a standstill beside him there and HaShem called out his [Moshe's] name: ${ }^{12}$

34:6 And HaShem passed by opposite him and HaShem called out

HaShem is a merciful compassionate god and slow to anger and has benevolence and truth:

34:7 Showing benevolence to the thousands [i.e. to the throngs waiting for cleansing in the heavenly processes of resurrection $],{ }^{13}$ forgiving iniquity and transgression and sin, He will not cleanse the ordained | The iniquity of the fathers unto the sons and unto the sons of the sons unto the third [generation] and unto the fourth (https://mechonmamre.org/c/ct/c0.htm):

\section{And Numbers 14:18:}

\section{במדבר פרק יד

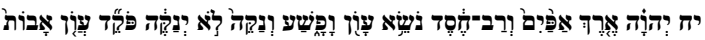

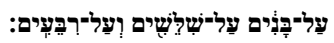

14:18 HaShem is slow to anger and has benevolence, forgiving iniquity and transgression, $\mathrm{He}$ will not cleanse the ordained | The iniquity of the fathers unto the sons unto the third [generation] and unto the fourth:

Also the Book of Jonah, an earlier biblical book:

יונהא

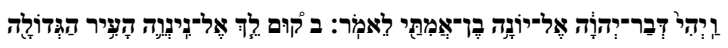

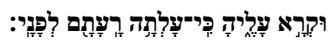

Jonah 1:1 And the word of HaShem was with Jonah son of Amittai saying:

Jonah 1:2 Arise go to Nineveh the great city and call out to it that their evil ascended to Me: [and so on ....]

\footnotetext{
${ }^{8}$ Nineveh was flooded once before as described in the Book of Yonah. See also II Kings 14:25.

${ }^{9}$ Its control מעטהו: the literal meaning of מטה is "staff."

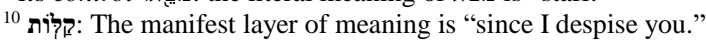
The underlying layer of meaning is "for making [things] easier for you." This is done by using a verb that has two meanings, one the opposite meaning to the other.

${ }^{11}$ All translated passages from the Hebrew Bible are new translations. All Hebrew texts are taken from the Torah Database: https://mechon-mamre.org/c/ct/c0.htm).

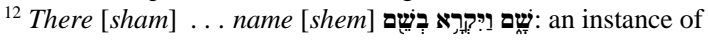
using words with similar sounds but different meanings - a poetic device demanding an oral reading.

${ }^{13}$ See the Pahlavi (Middle Persian) texts of the Zand-Avesta (Zoroastrian scripture) on the Creation.
} 
As well as a later comment on the events of the Book of Jonah in II Kings 14:25:

מלכים

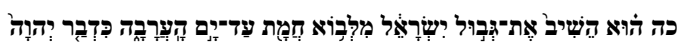

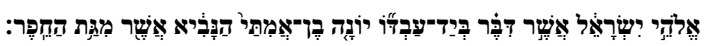

14:25 He restored the border of Israel from the entrance of Hamāh up to Wādī 'Arabah in accord with the word of HaShem Elohei Yisra'el that was spoken by his

servant Jonah, the son of Amittai, the prophet, who was from Gat-Hefer.

The climax of the Nahūm's poem is reached with the line "since plunder of wealth makes them confused and like their patriarch intoxicated . . (1:10), a line that points to the story of Noah's intoxication as described in Genesis 9:24:

בראשית כד

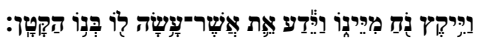

9:24 And Noah awoke from his wine and knew what his younger son had done to him:

\section{On The Structure and Poetic Features of the Book of Nahiūm}

In the 1990s, their textual criticism following in Hermann Gunkel's (d. 1932) footsteps, accomplished Christian scholars made progress in understanding the Book of Nahūm. They succeeded in pointing to features of the structure and various poetic devises. However, being unfamiliar with the oral genres born in oral societies they were unable to adequately interpret or translate it. They were puzzled and obsessed by Hermann Gunkel's discovery of an apparent acrostic. Oswald T. Allis in his article of 1955 describes the first five verses of Nahūm's panegyrical poem as forming "ten metrical lines (distiches)." $\mathrm{He}$ goes on to mention Gunkel's notion that there is a semblance of an acrostic. Here let us turn to another scholar who has taken the obsession with an apparent acrostic to its nth final absurdity. Thomas Renz in a well-written article published as recently as 2009 reviews multiple scholarly contributions puzzling over Gunkel's discovery, and comes up with yet another fantastically complicated solution encapsulated in the title of his article: $A$ Perfectly Broken Acrostic in Nahum 1? (Renz, 2009). The present writers acknowledge the discovery of acrostics (with thanks), but do not see a problem! There could well be vestiges of more than one acrostic remaining from differing renditions in oral readings (readings from memory) in Hebrew, Kurmanji Kurdish and later

\footnotetext{
${ }^{14}$ The aforementioned Kurdish poet Salīm Barakāt also uses poetic sound devices in his Arabic Islamic literary Shāhnāma.
}

in neo-Aramaic (Judaeo-Aramaic). An acrostic served as a memory aid for the bard. Turning once more to Allis, this scholar rightly goes on to comment that "Nahūm" is a Hebrew poet with an "unusually extensive vocabulary" and in the same breath struggles to justify the poet's use of structures that "sandwich (Allis, 1955)." The "sandwich," as Chyet has dubbed it, is a characteristic of the Kurdish language. To be specific, Kurdish grammar was initially characterized by compound words, and then more complex grammar using the circumflex or ambiposition (Chyet, 1999).

Nahūm followed the Mosaic religion, and it seems was a Kurd whose family came from the north of Syria. He introduced features of Kurmanji oral literature into his Hebrew poem. However, it is safe to conclude that as a biblical scholar he initially composed his Book in Hebrew; and then as said the poem passed through various translations and renderings before arriving at the final Hebrew redaction and finding its way into the canonized text of the Hebrew Bible. Allis is again on the right track when under his heading "Repetition, Assonance, Alliteration, Paronomasia in Nahum," he points to Nahūm's ability to use poetic devices entailing sound (Allis, 1955). These devices call for an oral reading of the Book of Nahüm, enhancing the public character of the content and causing Nahūm's prophecy to once again resound. ${ }^{14}$ The relevance of Nahūm's Book to our present world situation calls for a separate study.

\section{The Need for Orality in Traditional Societies}

Clearly Nahūm was well-acquainted with especially the Five Books of Moses and other scripture such-as-it-was before the canonization of the Hebrew Bible. Being a Hebrew scholar, he would have been highly literate. Therefore, it is safe to say that Nahūm's Book was the product of a written culture. His family would have come from where the culture was Kurdish and the geo-political situation produced bilingualism with neo-Aramaic, which is to say, they came from the north of Syria. Nahūm's family along with others went to where there were Kurdish communities living in and around Nineveh, including the deportees from the northern kingdom of the Kingdom of Israel, namely Samaria. Living near Nineveh in al-Qūsh, Nahūm and others would have brought with them the language(s) of the general community of their origins, namely Kurmanji Kurdish and neo-Aramaic and also Hebrew as the language of their religion. Nahūm's poem uses the style and structure of Kurmanji poetry. Introducing the Persian-Kurdish genre Shāhnāma into Hebrew religious literature, he provides a tongue for Hebrew 
scripture that precedes his own; and his poem abounds, in particular with words that play on "sound."

To provide the numbers of disconcerted Western biblical scholars with an explanation for the remnants of acrostics found in our received text. The final redaction of Nahūm's Book ignored vestiges of acrostics used by various bards as memory props to perform (sometimes with musical accompaniment) their own improvisations on Nahūm's written style.

The Middle Persian (Pahlavi) "northern" environment in which lived the Kurmanji-speaking Kurds of Syria was a crossroads of cultures and an intellectual center. Kurmanji Kurdish culture subsumed as it was in the greater Persian culture of three Persian Empires could not escape the controversy between sound, light, and the Word, as the means of the creation of the world in which we live. The Hebrew Bible records these diverse viewpoints, a subject that is beyond the scope of this study. However, what can be said is that the vitality of the religious and cultural life from the viewpoint of a conqueror would have justified the Assyrian move to deport sections of the population. The Kurmanji speaking communities were part of the Persian branch of civilization, and thus not separate from assumptions basic to Persian literary creativity such as sound in creativity, sound being basic to communicate meaning. To quote Kłagisz, "Zoroastrianism considers sound as a religious tool. In Middle Persian writings we can read that:

zīndag gōwšnīg saxwan az $\bar{a} n \bar{l}$ pad nibišt mādagwardar hangārdan čimìg.

It is reasonable to consider the living spoken word more important than the written....

This strong conception of a text as something existing only thanks to oral realization is still alive in the Iranian world. . . The very first examples of Middle Persian writings comprise royal inscriptions and some ostraca found near Nisa in today's Turkmenistan ... . writing was not used for religious and/or imaginative works until the early centuries of the Christian era (Kłagisz, 2014)." Worthy of note is that even now in Jewish ritual, prayers are said by speaking them (at times in an undertone), and the Torah is intoned aloud (with a second reader watching the handwritten Torah scroll in case of a mistake in the "reading"). In Muslim ritual, prayers and scripture are "read" uttered aloud by memory. In both cases the public "reading" of the Book has a strong impact even when the language is not understood.

\footnotetext{
${ }^{15}$ The Kingdom of Israel was unified under King David in circa 1035-970 BCE.
}

\section{The Jews of Kurdistan and Their Lineage}

II Kings 17:6 tells of the 722 BCE Assyrian deportation of the population of Samaria, ten tribes of the Twelve Tribes of Jacob. The deportees of this deportation are described as settling in communities scattered roundabout the Assyrian capital city of Nineveh:

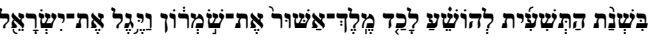

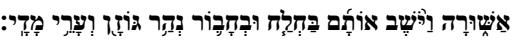

In the ninth year of Hosea, the king of Assyria took Samaria and exiled Israel to Assyria and settled them in Halah and in Habor (by the) Gozan River and (in the) cities of Medes:

II Kings mentions nine tribes of Israel who along with the tribe of Ephraim came to be known as the "Ten Lost Tribes of Israel (Ephraim Jewish Tribe, 1998)." The aggadic interpretation handed down to us concerning the deported Samarian population as the lost ten tribes implies that the entirety of the peoples with lineages from the ten tribes of Israel populated the northern Kingdom of Israel. However, this could not have been and was not the case even as evidenced by linguistic proofs. The Kingdom of Israel was in an area where Aramaic is known to have been the lingua franca, so the population would have spoken Hebrew and also neo-Aramaic, that is to say, Judaeo-Aramaic. ${ }^{15}$ Whereas, in the north of Syria there were Kurdish Jews who besides their familiarity with Hebrew, being Kurds spoke Kurmanji Kurdish, and possibly Aramaic of one sort or another. Moreover, they lived in former Iranian territories under the rule of the Shahs of Persia. As seen by analyzing the Book of Nahūm, the poet was fully acquainted with both Hebrew scripture and the art of writing poetry in the Kurdish Persian genre Shāhnāma. Therefore, it is clear that Kurmanji already had a corpus of oral scripture, ritual and dramatic literature well before Nahūm's time. In the absence of any account, it must be assumed that Nahūm's family emigrated either in a separate deportation or of their own free choice also about 2,500 years ago. The Assyrians, and also the Babylonians carried out other deportations, during which time some of the inhabitants did not accompany the deportations, but did disperse (Neubauer, 1888). With the fall of both Samaria and Judah, the concepts of "the remnant of Israel" and the "ingathering of the exiles" came into being.

Nahūm's Book was composed shortly before the fall of Nineveh (612 BCE). It could have been Nahūm's father but more likely his great-grandfather who had resettled the family in nearby alQūsh, making Nahūm of the fourth generation. The Book of Nahūm hints at Nahūm's lineage by pointing to the Five Books of Moses. The poet uses the same vocabulary as Exodus 34:6 to 
describe HaShem (Nahūm 1:3). Thus our attention is turned to the biblical verses in the background of Nahūm's poem. Next Exodus 34:6 leads us right into Exodus 34:7, verses that elaborate on Exodus 34:6:

Exodus $34: 7$ [He] shows benevolence to the thousands, forgiving iniquity and transgression and $\sin$, He will not cleanse the ordained | The iniquity of the fathers unto the sons and unto the sons of the sons unto the third [generation] and unto the fourth

The "thousands" of Exodus 34:7 can be understood as being the tribes of Israel, the crowd. The "ordained," then is the one with authority who will not be "cleansed" of his responsibility, in this case the prophet Nahūm. It follows that Nahūm is of the tribe of Judah. The same tribe from whence came King David. Could that explain Nahūm's outstanding poetic talent!

Al-Qūsh, now an Assyrian village in the Nineveh plains is still there, as is the prophet Nahūm's shrine. Nineveh is an archaeological site under and across the river from modern Mosul in what is the Kurdistan region of Iraq. Speaking of the about 100,000 Jews of Kurdish background in Israel today, Birgit Ammann says:

The native language of the dwindling first generation of migrants is Aramaic, which resembles modern Hebrew and in Israel by mistake is sometimes called Kurdi. Their second language is quite often Kurmanji-Kurdish or Sorani-Kurdish, besides that

Turkish, Persian or Arabic and of course modern Hebrew. The elder generation still strongly identifies with Kurdistan . ... .(Birgit, 2019).

As said, the Jews of Kurdistan are also referred to as "Kurdish Jews." The question arises as to how Nahūm and other Kurdish Jews came by their Kurdish Jewish lineage. At this point, the issue gets complicated. Birgit Ammann comments:

... the Kurdish Jews can by no means be summed up with the Iraqi Jews [the Baghdadi Jews or Jews in the South]. In an ethnic sense, with all the political implications, their loyalty was to their Kurdish setting and not to the Arab or

Turkish culture. The same obviously goes for Iran: of the city of Sanandaj for instance it is said that the Jews there considered themselves Kurds and that in their cultural and social patterns they did not vary greatly from those of the predominant Kurdish society (Birgit, 2019).

It seems that at one stage there was a widespread population of Kurds and Jews, and that that meant there was a widespread Kurdish Jewish population. The earliest writing, we know of is "cuneiform." It was used as a script for any peoples of the Near East wanting to write; its usage therefore does not say anything about a society's culture or identity.

\section{Conclusions}

From textual analysis of the Kurdish prophet's Hebrew Book, it is clear that there was a well-developed literary tradition in Kurmanji Kurdish at the time of his writing. That is to say, Nahūm was able to avail himself of the Kurdish oral tradition of poetry when writing down his prophetic utterance in Hebrew. Thus, because Nahūm was a Kurdish Jew who had adopted the written literary tradition of Mosaic religion, his writings in Hebrew have passed on to us evidence of the antiquity of Kurmanji Kurdish. He was acquainted with not only other biblical texts in his times still uncanonized, but also with what might have been an even earlier Kurdish tradition. He wrote at the time of the decline and imminent destruction of the great Assyrian civilization and just before Kurdish civilization would give way to the Medes conquest and the rise of the three great Persian empires. Of historical interest is the connection of the Kurdish nation in Nahūm's times to outlying regions due to numerous deportations and their dispersal when fleeing from their powerful enemies. Speculation on their connection with the tribes of Israel is at this point unresolved. The narrative of the next two sections of The Book of Nahūm gives every indication of the northern Kurmanjispeaking Kurds having very close connections with the tribes of the ancient Kingdom of Israel. As an aside, the unwinding of meaning found in Nahūm's Book through an understanding of the literary and linguistic background as well as the prophetic standing of Nahūm is an important contribution to those who see the Bible as the foundation of their religious belief.

\section{References}

1. Allis, O. T. (1955). Nahum, Nineveh, Elkosh. Evangelical Quarterly, 27.2. Available at: https://biblicalstudies.org.uk/pdf/eq/1955-2 allis.pdf

2. Barakāt, S. (2016). Selim Berekat Interview on Kurdsat, Awaza Çiya official channel. Available at: https://www.youtube.com/watch?v=AH4KnpklXEU.

3. Butt, A. (2020). Book Preview: Qamishli Extended: Salīm Barakāt and Maḥmūd Darwīsh, the Kurdish and Palestinian Similitude: With Anthology of Poems. In: 2020d 4th ECLSS International Online Conference Kyrenia / TRNC September 8 - 9, 2020 Proceedings Book: 35-41. Available at: www.eclss.org/cyprus

4. Birgit, A. (2019). The Kurdish Jewish Communities Lost Forever. In: edited by Khanna Omarkhali, Religious Minorities in Kurdistan: p. 296.

5. Butt, A. (2020). Salīm Barakāt as Arbiter between Good and Evil: According to His Long Poem al-Mu'jam (The 
Obscure). International Journal of Kurdish Studies, 6 (1), pp. 52 - 69. https://doi.org/10.21600/ijoks.516511

6. Chamanara, B. (2013). An Investigation into the Kurdish Genre of the Shāhnāma and Its Religious Dimensions. Brill's Journal of Persianate Studies: 163-177.

7. Karacan, H. (2020). Kurmanji and Zazaki Dialects: Comparative Study on their Phonetics. International Journal of Kurdish Studies, 6 (1), 35-51. https://doi.org/10.21600/ijoks.653812

8. Karacan, H, Khalid, H. (2016). Adjectives in Kurdish language: Comparison between dialects. International Journal of Kurdish Studies, 2 (2), 0-0. https://doi.org/10.21600/ijks.76230

9. Kłagisz, M. M. (2014). Oral Character of Middle Persian Literature - New Perspective. Poland: Rocznik Orientalistyczny (Yearbook of Oriental Studies) No. 1: 151-168. Available at: https://journals.pan.pl/Content/82233/mainfile.pdf?handl $\underline{\text { er }=p d f}$

10. Neubauer, A. (1888). Where Are the Ten Tribes? I. Bible, Talmud, and Midrashic Literature. The Jewish Quarterly Review, Vol. 1: 14-28 (University of Pennsylvania Press). Available at: https://www.jstor.org/stable/1449853

11. Noorlander, P. M. (2014). Diversity in Convergence: Kurdish and Aramaic Variation Entangled. Kurdish Studies, 2/2: 201-224. Available at: https://ideas.repec.org/a/mig/ksjrnl/v2y2014i2p201224.html

12. Omarkhali, K. (2019). Religious Minorities in Kurdistan: Beyond the Mainstream. Wiesbaden: Harrassowitz Verlag. https://doi.org/10.4000/abstractairanica.45169

13. Radnia, Z. (2020). Morphosyntactic Behavior of the Preposition la in the Structure of Sorani Kurdish Verbs. International Journal of Kurdish Studies, 6 (2):151-163. https://doi.org/10.21600/ijoks.701389

14. Renz, T. (2009). A Perfectly Broken Acrostic in Nahum 1? The Journal of Hebrew Scriptures, vol. 9, Article 23. https://doi.org/10.5508/jhs.2009.v9.a23

15. Chyet, M. L.(1990). Em hînî Kurmancî dibin [Let's Learn Kurmanji]. (Updated 1999). Available at: https://www.scribd.com/document/302602640/ingilizikur $\underline{\text { di }}$

16. King James Bible Online. Available at: https://www.kingjamesbibleonline.org/Nahum-Chapter$1 /$

17. Manchester University Project. Available at: http://languagecontact.humanities.manchester.ac.uk/ and ELA/. http://kurdish.humanities.manchester.ac.uk/
18. Torah database. (2018). Available at: https://mechonmamre.org/c/ct/c0.htm 